\title{
Seasonality, water use and community management of water systems in rural settings: Qualitative evidence from Ghana, Kenya, and Zambia
}

\section{Emma Kelly *, Katherine F. Shields, Ryan Cronk, Kristen Lee, Nikki Behnke, Tori Klug, Jamie Bartram}

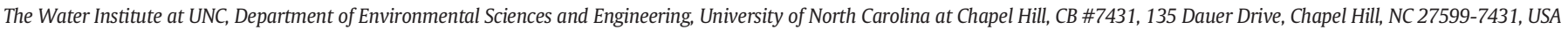

\section{H I G H L I G H T S}

- Seasonal availability of surface and rain water affects use of water system.

- Some types of breakdowns are more common in the rainy or the dry season.

- Seasonality affects committee activity, resource mobilization and external support.

- O\&M may be more achievable in the dry season.

- Extended, iterative community engagement leads to more effective water committees.
G R A P H I C A L A B S T R A C T

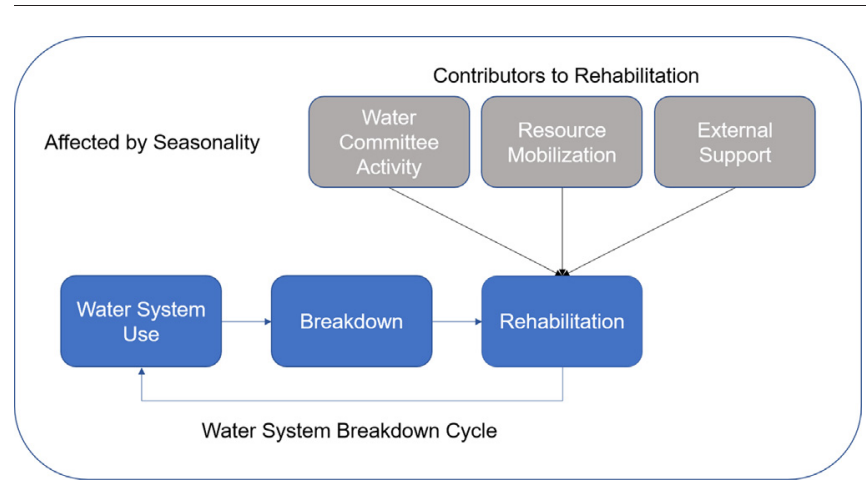

\section{A B S T R A C T}

The sustainability of rural, community-managed water systems in sub-Saharan Africa depends in part on the ability of local water committees to repair breakdowns and carry out the operation and maintenance (O\&M) of the system. Much of sub-Saharan Africa has two distinct seasons that affect the availability of water sources and how people use water. Little is known about how seasonality affects water system management. This qualitative study is based on 320 interviews and focus group discussions and examines the effects of season on community water use and management in Ghana, Kenya and Zambia. Participants revealed that seasonality affects water availability, water system breakdowns, resource mobilization, committee activity, and external support availability. In the rainy season, participants typically reported spending less time and money on water collection because rainwater harvesting and seasonal streams, ponds, wells and reservoirs are available. In the dry season, people used improved groundwater sources more often and spent more money and time collecting water. Although seasonal changes in household water demand and use have been examined previously, our data suggest that seasonality also influences community management through differential water system use, system breakdowns and management characteristics. We found that water committees generally have less money, time and access to external support during the rainy season, making them less able to carry out O\&M. Our results suggest that community engagement should take place over a long period of time so that seasonal patterns in management can be understood and incorporated into water committee training. External support actors should make a more targeted effort to understand the cultural and economic patterns in a community in order to train committees with appropriate management strategies. 


\section{Introduction}

An estimated $20 \%$ of community handpumps in sub-Saharan Africa are non-functional at any given time (Banks \& Furey, 2016) and most system breakdowns occur three to five years after construction. Because all water systems eventually break down, it is important to ensure that water systems are managed effectively and rehabilitations can be carried out quickly. Community management is a common management model in rural sub-Saharan Africa, especially in places where government support for rural water service is lacking (Arlosoroff et al., 1987; Briscoe \& de Ferranti, 1988). In this model, a community water committee assumes responsibility for the operation and maintenance (O\&M) of a water system installed by an external support actor, such as the government or a non-governmental organization (NGO).

The sustainability of community-managed water systems is dependent on both technical characteristics of the system and the management characteristics of the water committee. Klug et al. (Klug et al., 2017) examined the pathways through which a water committee could successfully rehabilitate a broken-down system, as well as the obstacles which hinder system repairs. The study found that committees could rehabilitate systems through several pathways, but all of these required the mobilization of financial resources and most included support from external support actors. Other studies have emphasized the importance of resource mobilization (Behnke et al., 2017; Smith School Water Programme, 2015), committee activity level (Fisher et al., 2015) and community characteristics such as social capital, sense of ownership and participation (Kelly et al., 2017; Marks et al., 2014; Marks et al., 2013). Sometimes the water committee is not able to carry out repairs, and therefore the importance of accessible external support has been widely recognized in the context of communitymanaged systems (Bakalian, 2009; Bey et al., 2014; Cronk \& Bartram, 2017; Whittington et al., 2009).

Seasonality can also affect the functionality of community-managed water systems in sub-Saharan Africa (White et al., 1972). Most of subSaharan Africa experiences a long dry season (ranging from 4 to 11 months/year) where there is less than $25 \mathrm{~mm}$ of rainfall per month (MacDonald et al., 2009). There is a substantial decrease in the quantity of water available during the dry season. Groundwater availability (the water source for wells and boreholes) (Eilers et al., 2007) and surface water area (Kaptué et al., 2013) both rapidly decrease in the dry season and rainwater harvesting becomes difficult. Seasonality has been shown to influence water demand in rural households (Calow et al., 2010; Griffin \& Chang, 1991), choice of primary water source (Pearson et al., 2016) and willingness to pay for water (Schweitzer et al., 2013). There is little evidence exploring how seasonality affects water system management, especially in the rural community management context.

This study explores how seasonality affects the cycle of use, breakdown and repair for community-managed rural water systems in Ghana, Zambia and Kenya. Although previous studies have identified seasonal variations in water access (Calow et al., 2006), demand (Arouna \& Dabbert, 2010; Pearson et al., 2016) and quality (Kumpel et al., 2017), there are no studies which examine the effect of seasonality on management practices. The objective of this study is to describe how seasonality affects community management - including water committees and external support actors - for the first time. We explore the effects of seasonality on community management by examining its effects on a typical water system breakdown and rehabilitation cycle. For both the rainy and dry seasons, we first describe seasonal water system use and its effects on water system breakdowns. We then identify the ways in which both water committees and external support actors respond differently to breakdowns in each season.

This study is part of a larger, hypothesis-generating examination of successful community-managed water systems. It is a common practice in water management research to identify causes of failure. Alternatively, this study examines successful systems because success is not solely the absence of failure. Water system success consists of more factors than functionality alone, and a system that experiences failure can still be considered successful if it is managed such that it can be rehabilitated. Although the qualitative, descriptive nature of this study disallows proof of causality or magnitude of effect, in-depth interviews and FGDs with the users and support actors of successful water systems allow us to learn about previously unidentified relationships. The goal of this study is to describe those relationships so that they may be further examined in larger settings, using quantitative methods.

\section{Methods}

This study is part of a qualitative exploration of the sustainability of community-managed water systems in sub-Saharan Africa. Eighteen communities were included from Zambia, Ghana and Kenya (six communities in each country). The communities were eligible if they had a successful, community-managed improved water source installed by World Vision. An improved water source is defined as a source that "by the nature of its construction and design adequately protects the source from outside contamination, in particular by fecal matter" (WHO, 2011). Our indicator of "success" was defined as functional at the time of a 2015 monitoring evaluation (Kayser et al., 2015). The improved water sources included in this study were either handpumps or mechanized systems (powered by solar energy or diesel fuel). Water could be accessed either at a communal kiosk or within the household via distribution networks.

Individual interview guides, focus group discussion (FGD) guides and community mapping activities were developed to collect information from community members, community leaders, water committee members and external support actors (Table 1). Full interview and FGD guides are included in the supplementary materials of Behnke et al. (Behnke et al., 2017). External support actors included government entities, non-governmental organizations (NGOs) or private companies outside of the community that provide financial or technical assistance. These groups of stakeholders were selected as study participants in order to gain a balanced and complete understanding of the practical application of the community management model. Community member individual interviews and FGDs aimed to assess how community members contribute to the functionality of the water system, how they benefit from the water system, and how they perceive the water system and the activities of the water committee. Water committee member individual interviews and FGDs aimed to examine water committee knowledge and management techniques, how the committee has overcome obstacles, and what inputs are necessary for continued support of water system functionality. External support actor interviews accompanied insight gained from interviews with water committee members and community members to gain insight as to what external support helps to maintain the functionality of community-managed water systems.

Researchers spent approximately one week in each of the study communities between June and August 2015 conducting interviews, FGDs and mapping activities. The total number of activities conducted

\section{Table 1}

List of research activities conducted, with total number of times each type of research activity was conducted - first seen in Behnke et al. (Behnke et al., 2017).

\begin{tabular}{lll}
\hline Activity type & Participant(s) & $\begin{array}{l}\text { Number of } \\
\text { recordings }\end{array}$ \\
\hline Individual interviews & Water committee member & 92 \\
& World vision staff & 34 \\
& Community member & 65 \\
& Other local leader & 49 \\
& Post-construction support provider & 23 \\
Focus group discussions & Water committee members & 19 \\
& Community members & 20 \\
Grand tour and community mapping & 48 \\
Total number of recordings & & 320 \\
Total hours of recordings & & $237 \mathrm{~h}$ \\
\hline
\end{tabular}


is listed in Table 1. External support actors were interviewed both inside and outside of communities depending on their positions. All study activities were recorded, translated into English and transcribed. The transcripts were then uploaded into an online qualitative data analysis software, Dedoose (Dedoose, 2015). Field notes and discussions among researchers from each country were used to develop an initial codebook. This preliminary codebook was used for the first stage of a two-stage coding process. Each transcript was reviewed and coded during the first stage as the codebook was refined. A final codebook with 308 codes was finalized at the end of stage one. All transcripts were reviewed again during the second stage of coding to ensure that: each had been reviewed by two different researchers; and all transcripts had been reviewed with the complete codebook - see Behnke et al. (Behnke et al., 2017) for the complete codebook.

Code co-occurrences between "seasonality" and any other code were analyzed to identify major themes. All excerpts that included the code 'seasonality' were reviewed and categorized into major themes including household water use, hardware breakdowns, water committee management and external support. In order to gain a better understanding of the effect of seasonality on use, every household interview was reviewed and all water use information was extracted and organized into an Excel spreadsheet. This information included water collection times, primary domestic source, dry and rainy season sources and other data on household water collection and use (see Supplementary Materials). Household data were used to illustrate community water use in each season; then this information was used to provide context to a narrative of seasonal breakdowns, water committee response and external support.

Please see Behnke et al. (Behnke et al., 2017) for detailed project methods.

\section{Ethics statement}

Ethical approval and all relevant research permits or exemptions were received from the University of North Carolina at Chapel Hill (exemption, project 15-0902), Ghanaian Ministry of Water Resources, Works and Housing (physical project approval letter, reference number SCR/JQ-52/173/049), Kenyan National Commission for Science, Technology and Innovation (physical permits, NACOSTI/P/15/8498/6556 and NACOSTI/P/15/8024/6557) and Zambian Ministry of Housing and Local Government (physical approval letter, reference number MLGH/ $101 / 18 / 22)$

\section{Results}

Almost all of the water systems included in this study had experienced at least one breakdown. Because these "successful" systems experienced breakdowns, we found that success was as dependent on the ability to carry out repairs as the avoidance of water system failure. We consider a lifecycle of water system use, breakdown and rehabilitation to be the normal state of a water system (Fig. 1). Participants described how seasonality affected all phases of the water system lifecycle, as well as several management characteristics that contribute to rehabilitation - water committee activity level, resource mobilization and availability of external support.

\subsection{Rainy season}

Four ( 4 of $18,22 \%$ ) of the communities included in this study had solar-powered mechanized water systems. During the rainy season, solar-powered systems did not operate or operated for reduced hours due to increased cloud cover. One community member in Kenya explained "We are almost in July, when the weather will actually change to cloudy; at that time this [solar-powered] system cannot work because it depends on light intensity. That means at that time people will not access this water." For solar-powered systems with communal kiosks, water committees either closed the kiosks for the entire rainy season or only opened them for certain hours or days. Communities with piped household connections employed line patrollers to ration water by systematically opening and closing access to parts of the network. Communal handpumps operated normally during the rainy season.

A total of 65 individual community member interviews were conducted. Most community members ( 49 of $65,75 \%$ ) reported using multiple water sources (MSU). Of the 47 respondents who elaborated on their MSU decision making process, 24 (24 of 47, 51\%) indicated that the availability/breakdown of their primary source was a main factor in choosing a water source. 22 community members (22 of 47, 47\%) said that their MSU decision was affected by convenience, meaning

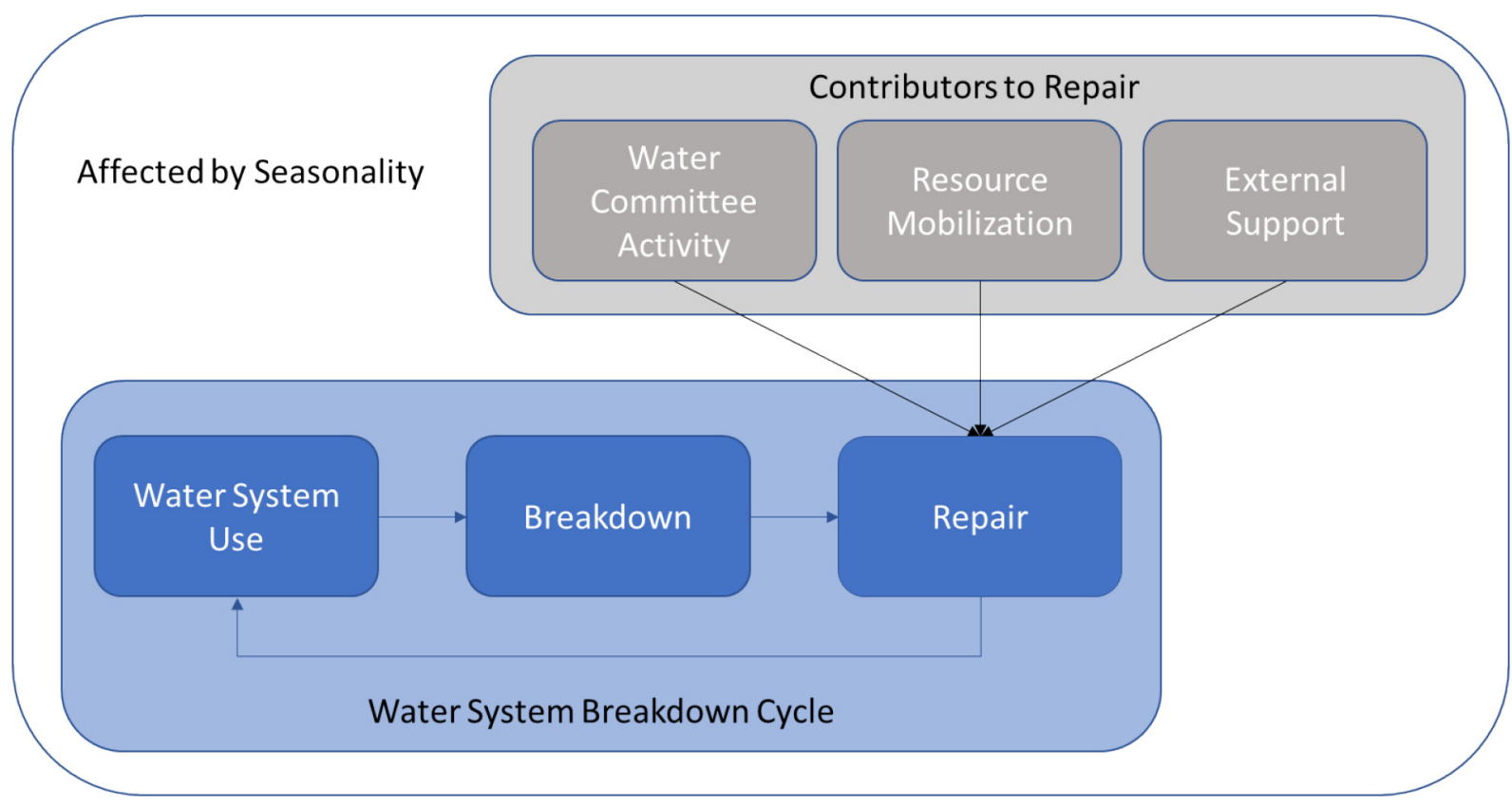

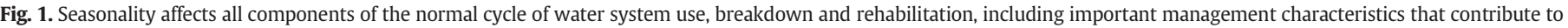
rehabilitation. 
that they would access water at the nearest location to their house or workplace. Only 19 (19 of 47, 40\%) listed water quality as a factor in their MSU decision-making. Participants reported that more water sources were available in the rainy season, when increased rainfall led to the formation of seasonal surface water sources including streams, shallow wells (typically hand-dug), reservoirs and seasonal rivers. Eight participants ( 8 of $47,17 \%$ ) also reported using harvested rainwater as an alternative source of water during the rainy season. Generally, people collected water less frequently, walked shorter distances and spent less time collecting water during the rainy season. For example, one community member in Zambia told us that all of her neighbors used closer alternative sources when they were available; "It's far to come to the borehole; so all of us far from the borehole, during the rainy season we use shallow wells."

Study participants also reported different types and/or causes of breakdowns between seasons. In the rainy season, flooding caused many of the water system breakdowns. Floods and the advent of seasonal streams washed away intake pipes (from earth dams or rivers) and the distribution lines of piped systems. In Kenya, a community member explained, "During [the] rainy season you know there are floods and the pipe crosses the stream, so this pipe is driven away by the water. And then the committee has to make arrangements and make repair[s]." Flooding was also a problem for one Kenyan system with a diesel fuel motorized pump, which sustained damage when submerged in floodwater. For handpumps, excess rainfall caused water-logging in the concrete apron at the foot of the handpump. Community members indicated that flooding compromised the apron and that the runoff led to contamination of the borehole - this perceived contamination led some community members to fetch water from other sources.

The ability of the water committee to repair water systems after breakdowns was also affected by season. Water committees were typically less active during the rainy season because MSU caused a decrease in demand for water from the improved water source. The water committee members were also typically busy on their farms. Water committees reported having fewer meetings in the rainy season than in the dry season. A water committee chairperson in Zambia told us "we have been calling for committee meetings but people have been busy this farming season." Community members who were not on the committee were also less willing to participate in meetings and communal labor to support water system repair and O\&M. Despite an overall reduction in time commitment, the water committee had to carry out rainy seasonspecific tasks. Water committee responsibilities that were specific to the rainy season included cutting back excess overgrowth near the water system and removing standing water, moss and mud from the base of the water system. These environmental hygiene tasks were perceived to be important to ensure that the concrete apron was preserved and the water in the system did not become contaminated.

Community members reported a wide variety of water fee structures. Of the 65 community members interviewed, 46 reported that they paid regular water fees (46 of $65,71 \%$ ). Monthly contributions were the most common type of water fee ( 28 of $46,61 \%$ ), followed fee based on volume of water ( 9 of $46,19 \%$ ), reactive fees ( 6 of $46,13 \%$ ) and annual fees ( 3 of $46,7 \%$ ). Reactive water fees are defined here as fees collected after a breakdown in order to raise money for repairs. These fee structures, along with alternative, non-monetary contributions are more fully detailed in Behnke et al. (Behnke et al., 2017).

For all types of payment structures, community members reported that they bought less water and/or paid fewer water system fees in the rainy season due to their ability to access cheaper alternative sources. A seasonal decrease in willingness to pay and overall availability of funds was common to all types of water systems. One Kenyan treasurer described this challenge: "Due to the plenty water during rainy seasons they don't pay money." Seasonal income also created an obstacle for resource mobilization in the rainy season. The study communities were agro-pastoral; households typically had the most money immediately after the harvest. The rainy season was just before the harvest, when people had the least amount of money and many community members were therefore less willing and less able to pay water fees (see (Behnke et al., 2017) for further information regarding resource mobilization). Although there was less money being collected in the rainy season, committees also experienced a reduction in system operational costs. Operational costs were directly related to the amount of water being drawn from the system over a period; these included electricity/fuel required for pumping in mechanized systems and the hourly wages of caretaker (as kiosks often reduced hours during the rainy season). The fixed costs of the water system were not affected by changes in use over time and therefore were relatively unaffected by seasonal use patterns.

The availability of external support differed between rainy and dry seasons. All of the study communities were rural and many were remote, which made them difficult to access during the rainy season. External support actors reported that they visited rural communities less often during the rainy season due to road flooding and lack of resources (including appropriate vehicles and rain jackets). During the rainy season, therefore, training activities were less frequent and less technical support was accessible by the communities.

\subsection{Dry season}

Alternative water sources were less available in the dry season. Shallow wells, earth dams, and seasonal springs often dried up during this season due to the lack of rain. Solar-powered groundwater systems and water vendors, on the other hand, became more available. Due to increases in both sunlight and demand, solar-powered systems were kept open for longer and more consistent hours. For example, one water committee chairman in Kenya described the schedule for the communal water kiosk: "During the dry season, the four kiosks are opened when there is need...During the rainy season the kiosks are not opened because you find that most of the people already [harvest rainwater] and especially for the animals some of them have dug those dams." Water vendors acted as an additional available water source during the dry season in some communities. One community in Ghana, for example, supplemented the water from their single borehole by buying drums of water from a water vendor truck which would come from the nearest urban center. This practice was most common during the dry season, when surface water sources were unavailable and roads were dry enough for the truck to reach the community.

Due to the lack of alternative sources, MSU was less common and people were generally more dependent on improved groundwater sources during the dry season. For example, a community member in Zambia said that she would collect water from the communal borehole 2-3 times a day during the dry season, but only 2-3 a week during the rainy season (and supplement this collection with water from alternative sources). Increased use of the improved water sources during the dry season caused crowding problems. One community member in Zambia explained "when it rains and everybody collects some of the rain water, then the borehole [is not] crowded; then, when the rain water finishes, the borehole becomes full again." Some water committees attempted to combat this problem by scheduling collection times according to use - for example, one committee allowed fetching water for animals during limited hours of the day. Along with crowding, community members also reported that low water tables caused even longer water collection times because each bucket of water took longer to fill. Generally, community members reported that they typically had to travel further, spend more time and pay more money to collect enough water; even with these efforts, community members often lacked sufficient water and had to forgo some domestic activities.

Like the rainy season, there were breakdowns that occurred in the dry season. Increased heat and dryness caused problems for piped water systems. Community members reported that the underground pipes would burst or crack during the dry season. One water committee member in Kenya told us "[One challenge] is the leakage...the PVC pipe 
sometimes bursts during drought season." Breakdowns caused by animals were more common in the dry season, when livestock would depend on the improved sources instead of surface water. Animals gathering near the water system also caused breakdowns in some cases, with cattle knocking down fences around boreholes, crushing the concrete apron or breaking the distribution pipes of mechanized systems. A community leader in Kenya explained that the school water system had this issue: "we sometimes experience... breakage of the water pipes; there are some areas [where] the pipe is shallow, so it can be damaged by animals."

Overall, water committees were more active during the dry season, allowing them to respond more efficiently to breakdowns. Committee members were more available to hold meetings and carry out O\&M because they had fewer responsibilities on their farms. Some committee members such as caretakers and kiosk attendants also worked more frequently due to increased demand on the improved water sources during the dry season. Dry season water committee responsibilities included water rationing during water shortages and increased water kiosk management. One community in Kenya, for example, hired six kiosk workers in the dry season and only two in the rainy season due to the higher demand and longer open hours. Community members not on the committee also participated more in communal labor and water system maintenance in the dry season due to their increased availability and dependence on the single source.

The water systems included in this study typically had greater operational costs during the dry season. Increases in operational costs for the water system reflected the increased use of the improved water source; more use led to higher fuel bills for mechanized systems which used diesel pumps and more hourly wages for kiosk attendants. Although the costs were higher in the dry season, water committees were also able to mobilize resources more successfully due to the increased demand. People were more willing to pay regular fees or contribute to repairs because the alternative, cheaper sources were less available. Mechanized systems which charged community members by unit of water especially benefitted from increased community demand. One community member in Kenya explained how drastic the seasonal payment changes were: "during dry season we use a lot of water and one can pay KSH 1000 up to KSH 2000 [about \$10-20 USD for the season] because there is no water during those days. We don't fetch during rainy seasons. We have other sources."

Finally, external support was more available during the dry season because external support actors could more easily access rural communities. This increase in support came in the form of more frequent training activities and more accessible technical support during breakdown rehabilitation. External support actors were also more likely to install new improved water sources during the dry season because aquifers identified in the dry season were considered more reliable and it was easier to drill without the rain. One local leader in Ghana explained that he got better responses from external support actors when soliciting a water system during the dry season because "when they go and drill the borehole in the rainy season and find water, when it gets to the dry season [the water table lowers]... So they want to drill in the dry season so that they get the normal distance of the water." The preference to implement water systems during the dry season was also confirmed by external support actors.

\section{Discussion}

The goal of this study was to use in-depth interviews and FGDs with various stakeholders to further our understanding of the nuanced relationships between people, their water systems and the environment. Although we selected systems which were identified as 'successful' using an indicator of functionality, we found that functionality was an insufficient measure and that the lifetime of a successful system comprised cycles of use, breakdown and rehabilitation (Fisher et al., 2015; Klug et al., 2017). A successful water system can therefore be thought of not as a system that does not experience failure, but as a system that is managed in a way that allows for quick rehabilitation and continued use.

With regard to water system use, we found that the improved groundwater sources were more heavily relied upon in the dry season, when fewer alternative sources were available. This finding agrees with previous studies which show that MSU is more common in the rainy season (Calow et al., 2006; Elliott et al., 2017; Pearson et al., 2016; Reyes Mason, 2014) and that water collection time and household water expenses increase during the dry season, when people are more dependent on handpumps and mechanized systems (Arouna \& Dabbert, 2010; Blum et al., 1987; Calow et al., 2006; Schweitzer, 2013; Tucker et al., 2015). Participants reported various reasons for their MSU decisions, which may give some insight into the cultural norms and priorities of rural households. Availability (including unavailability due to breakdown at the primary source) was listed most frequently as the main factor in MSU decisions - this response may mean that the household did not indeed have a "choice" but were forced to use whichever source was accessible at the time. Convenience or nearness was the priority of more community members than water quality was - this may be a reason to install mechanized systems with numerous standpipes or in-home connections instead of handpumps despite increased costs, as the benefits may be greater.

Previous literature has demonstrated that rural water access and use in sub-Saharan Africa is seasonal, yet management is still assumed to be consistent year-round. This study is the first to describe the seasonal nature of community management and water system rehabilitation. We found that seasonality affected the ability of the water committee to carry out O\&M by causing changes in water committee activity level, ability to mobilize resources and access to external support all. Water committees met less frequently, collected less fees, saw less community participation and were less able to access external support in the rainy season. Because of these challenges, there was often a complete management breakdown in the rainy season, when systems were closed or neglected by the water committee. However, we found that there was a natural cycle of management which allowed the water system to persist through the rainy season. Although the water committee was inactive, there was less money available and external support was inaccessible during the rainy season, there was also less demand for water from the systems due to the availability of other sources. Less demand meant: mechanized systems needed to purchase less fuel and pay fewer kiosk attendants (or operational costs are reduced); handpumps experienced less strain from use and therefore fewer breakdowns; and animals were less likely to cause damage to the water system because they could access water elsewhere. Thus, although O\&M activities were less consistent and less money is available, there were also typically fewer repairs to be made and fewer operational costs. Because both the ability of the water committee to carry out O\&M and the community need for the water system were both reduced in the same season, the water systems could often just "coast" with little attention.

The findings of this study suggest that major changes need to be made in how community engagement is carried out in the context of community management. In the early phases of community engagement, the implementing government or NGO - who we will refer to as external support actors - form and train a water committee to supervise O\&M. These committees become new institutions within the community; they create new norms and rules, as well as interact with community members and other organizations. The structure and rules of the new water committee are often dictated by the external support actor - water committee positions and gender balance may be prescribed, as well as rules regarding fee collection, meeting frequency and environmental hygiene practices (most commonly sweeping around the borehole). Although some NGOs and governments have engagement plans which are years long, resources often restrict the ability of the local offices to carry out those plans effectively. Furthermore, the actual water committee training are often carried out in a matter of days and secondary or "refresher" training is inconsistent or non-existent. 
We found that management practices vary on a seasonal scale, meaning that at least a full year of community engagement would be necessary to observe these cultural and economic patterns and that an even longer time would be necessary to incorporate these patterns into the water committee O\&M training. Iterative planning and implementation phases are necessary to build effective institutions (Abers, 2013) and in the case of rural water committees, very few external support actors are engaging with communities for enough time to accomplish those iterations.

Resource mobilization is one component of community management which is commonly misunderstood due to short community engagement periods. Current resource mobilization practices for communitymanaged rural water systems are considered to be insufficient for capital costs (Fonseca et al., 2013) or major repairs (Foster \& Hope, 2016). Inability to mobilize resources can seriously delay or disallow repairs, meaning that the community loses access(Foster \& Hope, 2016; Klug et al., 2017). Many external support actors place a heavy emphasis on regular fee collection, which is considered to be a significant determinant of water system sustainability (Cronk \& Bartram, 2017; Fisher et al., 2015; Foster \& Hope, 2016; Whittington et al., 2009). In many cases, water committees are encouraged to collect fees on a monthly basis, or on some other short interval. We found, however, that income varied by season in agro-pastoral communities and community members were not as willing to pay a water fee in the months preceding the harvest. Some water committees were able to adjust for these variations by collecting a larger annual fee after the harvest season (when funds were available) but other committees continued asking for monthly contributions as they were instructed. By prescribing frequent, regular fee collections external support actors may jeopardize cost recovery because they did not understand the long-term patterns in availability of funds. Furthermore, Behnke et al. (Behnke et al., 2017) found that there were numerous non-monetary resource mobilization practices that could replace or supplement fees. Non-monetary contributions such as piecework, communal farming and renting out school buildings, and may be important opportunities to include poor community members who do not have access to funds. Non-monetary contributions and appropriate fee structures are currently under-used in community management settings, but could be included in models that engage with the community long enough to identify challenges and resources.

Even if appropriate structures and rules are handed down during community engagement, institution building is also a transformative process that must "change ideas, as well as the resources and relationships around those ideas" (Abers, 2013). This is often a slow, iterative process. In the case of community-managed water systems, new financial and human resources must be mobilized to carry out O\&M (Klug et al., 2017). The relationship between the community members and their water committee may also need to change to facilitate collective action or participation (Kelly et al., 2017). In order to accomplish these tasks, the committee must establish "practical authority" (Abers, 2013), or the ability to influence behaviors through recognition and capacity. Recognition for the authority of the water committee depends on its social capital, which comprises the rules it makes, the trust of the community members and its reputation as an institution. Community entry is an important first step in building the social capita of the water committee. As described in Kelly et al. (Kelly et al., 2017), community participation in water system construction and water committee formation builds a strong basis of social capital for the committee, which can then be used to facilitate the community sense of ownership and further participation. If the external support actors use the early stages of community engagement to identify strong leaders and skilled community members, they can use those human resources to create a strong base of social capital, which affects how successfully a water committee can mobilize resources, share information and make decisions. This will set in motion a positive cycle of community trust, sense of ownership and participation which can lead to long-term success (Kelly et al., 2017).
The qualitative nature of this study is limited by the number of small case studies which could be carried out. Though direct observations were used to assess the functionality of the water systems at the time of data collection, extensive survey data was not collected for previous breakdowns. All breakdown and O\&M processes described here reflect the descriptions of the participants and are therefore subject to recall bias. Interview guides and FGD guides were tested and approved by the research team before data collection. We hope that future studies will use our findings as a basis for a quantitative study using a larger dataset in order to determine whether these relationships are significant determinants of water committee and system success. Further research may include surveys or interviews carried out in the same setting during different seasons in order to reduce recall bias, or include monitoring information about breakdowns or weather information.

\section{Conclusion}

Community-managed rural water systems in Zambia, Ghana and Kenya are greatly affected by seasonality due to variation in water availability, differences in system breakdowns and changing management practices. Seasonality affects the capacity of the water committee to carry out O\&M and repair breakdowns through resource mobilization, the level of water committee activity and access to external support. This study has therefore found that seasonal changes in weather affects each step in the breakdown and repair cycles of rural communitymanaged systems. Because community management varies significantly by season, it is important that we reevaluate how we engage with communities and prepare water committees. Community engagement must take place over a sufficiently long period of time to identify long-term, seasonal patterns in the community and incorporate these into the planning and strategy of the water committee. External support actors which fail to engage the community for at least one year may train water committees to use inappropriate management strategies because they are ignorant of community resources and challenges. The focus of external support actors must shift from water systembased implementations to water service-based ones; more resources should be used to engage with communities in the long term, as opposed to building new systems which communities are unable to maintain.

\section{Funding}

This project was made possible with support from World Vision, the Wallace Genetic Foundation, the Morehead-Cain Foundation, the American Water Works Association (AWWA), the BB Parker Fellowship, the Jon Curtis Student Enrichment Fund, the UNC Class of 1938 Fellowship and the Summer Undergraduate Research Fellowship (SURF). Ryan Cronk was supported by a training grant from the National Institute of Environmental Health Sciences (Grant Number: T32ES007018).

\section{Acknowledgements}

The Water Institute at UNC thanks team members from World Vision US and World Vision International Jordan Smoke, Ashley Labat and Greg Allgood for their valuable guidance of this project and the WaSH directors of the Ghana, Kenya and Zambia World Vision country offices, Bansaga Saga, Stephen Maina, Enock Oruko, Sebastian Kunda, and Emmanuel Nyundu for making field work possible. We also thank Julian Oliver and Leah Everist for their role in developing this study and conducting field work and Dr. Peggy Bentley, Dr. Valerie Flax and Vidya Venkataramanan for their guidance in the creation of study tools.

Special thanks are due also to the following groups from each of the three countries: World Vision national and ADP office staff, postconstruction support providers, local government officials, community leaders, and committee and community members for sharing their time and experiences with UNC researchers. This study would not have been 
possible without their participation. We would also like to thank the interpreters and transcribers in all three countries for their dedicated contribution to this study.

\section{References}

Abers, R.N., 2013. Practical authority, institution building, and entanglement. Practical Authority: Agency and Institutional Change in Brazilian Water Politics. 2.

Arlosoroff, S., Tschannerl, G., Grey, D., Journey, W., Karp, A., Langeneffer, O., Roche, R. 1987. Community water supply: the handpump option. UNDP and WB https://doi. org/10.1080/02508068808692009.

Arouna, A., Dabbert, S., 2010. Determinants of domestic water use by rural households without access to private improved water sources in Benin: a seemingly unrelated Tobit approach. Water Resour. Manag. 24:1381-1398. https://doi.org/10.1007/ s11269-009-9504-4.

Bakalian, A.W.W., 2009. Post-Construction Support and Sustainability in CommunityManaged Rural Water Supply.

Banks, B., Furey, S., 2016. What's Working, Where, and for How Long. A 2016 Water Point Update to the RWSN (2009) statistics. https://doi.org/10.1021/es402086n.Fisher.

Behnke, N.L., Klug, T., Cronk, R., Shields, K.F., Lee, K., Kelly, E.R., Allgood, G., Bartram, J., 2017. Resource mobilization for community-managed rural water systems: evidence from Ghana, Kenya, and Zambia. J. Clean. Prod. https://doi.org/10.1016/j. jclepro.2017.04.016.

Bey, V., Magara, P., Abisa, J., 2014. Assessment of the Performance of the Service Delivery Model for Point Sources in Uganda.

Blum, D., Feachem, R.G., Huttly, S.R.A., 1987. The effects of distance and season on the use of boreholes in northeastern Imo State, Nigeria. J. Trop. Med. Hyg. 90, 45-50.

Briscoe, J., de Ferranti, D., 1988. Water for Rural Communities. Helping People Help Themselve.

Calow, R., Macdonald, A., Nicol, A., Robins, N., Kebede, S., 2006. The Struggle for Water: Drought, Water Security and Rural Livelihoods.

Calow, R.C., MacDonald, A.M., Nicol, A.L., Robins, N.S., 2010. Ground water security and drought in Africa: linking availability, access, and demand. Ground Water https:// doi.org/10.1111/j.1745-6584.2009.00558.x.

Cronk, R.D., Bartram, J., 2017. Factors influencing water system functionality in Nigeria and Tanzania: a regression and Bayesian network analysis. Environ. Sci. Technol. https://doi.org/10.1021/acs.est.7b03287 (acs.est.7b03287)

Dedoose, 2015.

Eilers, V.H.M., Carter, R.C., Rushton, K.R., 2007. A Single Layer Soil Water Balance Model for Estimating Deep Drainage (Potential Recharge): An Application to Cropped Land in Semi-arid North-east Nigeria. https://doi.org/10.1016/j.geoderma.2007.03.011.

Elliott, M., MacDonald, M.C., Chan, T., Kearton, A. Shields, K.F., Bartram, J.K., Hadwen, W.L, 2017. Multiple household water sources and their use in remote communities with evidence from Pacific Island countries. Water Resour. Res. https://doi.org/10.1002/ 2017WR021047.

Fisher, M.B., Shields, K.F., Chan, T.U., Christenson, E., Cronk, R.D., Leker, H., Samani, D., Apoya, P., Lutz, A., Bartram, J., 2015. Understanding handpump sustainability: determinants of rural water source functionality in the Greater Afram Plains region of Ghana. Water Resour. Res. https://doi.org/10.1002/2014WR016770.

Fonseca, C., Smits, S., Nyarko, K., Naafs, A., Franceys, R., 2013. Financing capital maintenance of rural water supply systems: current practices and future. Options 40 .

Foster, T., Hope, R., 2016. A Multi-decadal and Social-ecological Systems Analysis of Community Waterpoint Payment Behaviours in Rural Kenya Tim Foster. 61:pp. 1-31. https://doi.org/10.1017/CBO9781107415324.004 (Forthcoming).
Griffin, R.C., Chang, C., 1991. Seasonality in community water demand. West. J. Agric. Econ. 16, 207-217.

Kaptué, A.T., Hanan, N.P., Prihodko, L., 2013. Characterization of the spatial and temporal variability of surface water in the Soudan-Sahel region of Africa. J. Geophys. Res. Biogeosci. 118:1472-1483. https://doi.org/10.1002/jgrg.20121.

Kayser, G.L., Guo, A.Z., Morgan, C., Oliver, J., Chan, R., Bowling, M., 2015. The World Vision Baseline Evaluation of Water, Sanitation, and Hygiene Programs.

Kelly, E., Lee, K., Shields, K.F., Cronk, R., Behnke, N., Klug, T., Bartram, J., 2017. The role of social capital and sense of ownership in rural community-managed water systems: qualitative evidence from Ghana, Kenya, and Zambia. J. Rural. Stud. 56. https://doi. org/10.1016/j.jrurstud.2017.08.021.

Klug, T., Shields, K.F., Cronk, R., Kelly, E., Behnke, N., Lee, K., Bartram, J., 2017. Pathways for water system hardware and management rehabilitation: qualitative evidence from Ghana, Kenya, and Zambia. Int. J. Hyg. Environ. Health https://doi.org/10.1016/j. ijheh.2017.02.009.

Kumpel, E., Cock-Esteb, A., Duret, M., de Waal, D., Khush, R., 2017. Seasonal variation in drinking and domestic water sources and quality in Port Harcourt, Nigeria. Am. J. Trop. Med. Hyg. 96:437-445. https://doi.org/10.4269/ajtmh.16-0175.

MacDonald, A.M., Calow, R.C., MacDonald, D.M.J., Darling, W.G., Dochartaigh, B.E.O., 2009. What impact will climate change have on rural groundwater supplies in Africa? Hydrol. Sci. J. J. Des Sci. Hydrol. 54:690-703. https://doi.org/10.1623/hysj.54.4.690.

Marks, S.J., Onda, K., Davis, J., 2013. Does sense of ownership matter for rural water system sustainability? Evidence from Kenya. J. Water, Sanit. Hyg. Dev. 3:122. https:// doi.org/10.2166/washdev.2013.098.

Marks, S.J., Komives, K., Davis, J., 2014. Community participation and water supply sustainability: evidence from handpump projects in rural Ghana. J. Plan. Educ. Res.: 1-11 https://doi.org/10.1177/0739456X14527620.

Pearson, A.L., Zwickle, A., Namanya, J., Rzotkiewicz, A., Mwita, E., 2016. Seasonal shifts in primary water source type: a comparison of largely pastoral communities in Uganda and Tanzania. Int. J. Environ. Res. Public Health 13. https://doi.org/10.3390/ ijerph13020169.

Reyes Mason, L., 2014. Beyond Improved Access: Seasonal and Multidimensional Water Security in Urban Philippines. https://doi.org/10.1007/s40609-014-0024-7.

Schweitzer, R.W., 2013. Community and Household Management Strategies for Water Supply and Treatment in Rural and Per-urban Areas in the Developing World. pp. 1-221.

Schweitzer, R., Pezon, C., Pinjari, A., Fonseca, C., Mihelcic, J.R., 2013. Household Expenditure on Water Service: Financial and Economic Expenditures of Rural and Periurban Households across Socio-Economic Classes and Seasons in Burkina Faso.

Smith School Water Programme, 2015. Financial Sustainability for Universal Rural Water Services - Evidence from Kyuso, Kenya.

Tucker, J., MacDonald, A., Coulter, L., Calow, R.C., 2015. Household water use, poverty and seasonality: wealth effects, labour constraints, and minimal consumption in Ethiopia. Water Resour. Rural Dev. 3:27-47. https://doi.org/10.1016/j.wrr.2014.04.001.

White, G., Bradley, D., White, A., 1972. Drawers of water II. Bull. World Health Organ. 80: 63-73. https://doi.org/10.3362/0262-8104.2003.039.

Whittington, D., Davis, J., Prokopy, L., Komives, K., Thorsten, R., Lukacs, H., Bakalian, A. Wakeman, W., 2009. How well is the demand-driven, community management model for rural water supply systems doing? Evidence from Bolivia, Peru and Ghana. Water Policy 11:696-718. https://doi.org/10.2166/wp.2009.310.

WHO, 2011. WHO guidelines for drinking-water quality. WHO Chron. 38:104-108. https://doi.org/10.1016/S1462-0758(00)00006-6. 